\title{
Geographical versus food plant differentiation in populations of Maculinea alcon (Lepidoptera: Lycaenidae) in Northern Hungary
}

\author{
Judit BERECZKI ${ }^{1}, \mathrm{KATALIN}_{\text {PECSENYE }}{ }^{*}$ and ZOLTÁN VARGA ${ }^{1,2}$ \\ ${ }^{1}$ Department of Evolutionary Zoology and Human Biology, University of Debrecen, Debrecen, Egyetem tér 1, Hungary; \\ e-mails: juditb@delfin.unideb.hu; pecskati@tigris.unideb.hu; zvarga@tigris.unideb.hu \\ ${ }^{2}$ HAS-DU Research Group for Evolutionary Genetics and Conservation Biology
}

Key words. Enzyme polymorphism, geographical differentiation, Lycaenidae, Maculinea alcon, Alcon Blue, “Cruciata” type, "Pneumonanthe" type

\begin{abstract}
The taxonomic status of Alcon Blues in Central and Western Europe (conventionally: Maculinea alcon and M. rebeli) is confused. Some authors distinguish them as separate species within the M. alcon species group, while others consider them to be subspecies or simply ecological forms. Our aim was to study the geographical versus food plant pattern of genetic differentiation among several populations of these taxa in Northern Hungary. Imagines were collected from 11 localities between 2000 and 2003. M. alcon feeding on G. pneumonanthe from three subregions and on G. cruciata from two subregions were analysed. Enzyme polymorphism was analysed at 16 enzyme loci using polyacrylamide gel electrophoresis. In the analysis of the data, $F$-statistics were computed and the total genetic variation partitioned into within and between population components. Nei's genetic distances were calculated and a UPGMA dendrogram constructed on the basis of the distance matrix. Hierarchical $F$-statistics and AMOVA were computed to study the pattern of genetic differentiation among the samples. PCA analysis was also carried out using the allele frequencies of the samples. The results of all analyses indicated strong differentiation among the samples. A sizeable portion of this variation was detected among the samples/generations collected from the same population. The distribution of the between population variation did not exhibit a clear split between the two food plant groups. In addition, the $F_{S T}$ values computed using a restricted data set suggested significant differentiation among the subregions. The results of AMOVA and PCA also indicated that the geographic pattern was more expressed in the between sample variation than the conventional taxonomic pattern.
\end{abstract}

\section{INTRODUCTION}

Alcon Blues in Europe are generally treated as two distinct species: Maculinea alcon ([Denis \& Schiffermüller], 1775 ) and M. rebeli (Hirschke, 1904), based on their initial food plants (Gentiana pneumonanthe vs. G. cruciata) and host ant species (Berger, 1946; Elmes \& Thomas 1987a, b; Thomas et al., 1989; Elmes et al., 1991a, b, 1994; Munguira \& Martin, 1999). Other authors, however, have considered them subspecies or ecological races, which are only slightly differentiated morphologically and have overlapping characters. Thus, they are difficult to separate taxonomically (Bernardi, 1947; Beuret, 1949, 1954; Kaaber, 1964; Urbahn, 1964; Ebert \& Rennwald, 1991). Moreover, Als et al. (2004) have recently pointed out the expressed genetic similarity and lack of phylogenetic differentiation among $M$. alcon and rebeli populations. A similar conclusion was drawn in another study, in which the phylogeny of the Maculinea species was reconstructed using 91 morphological and ecological characters (Pech et al., 2004). Nevertheless, the taxonomic judgement is still confused since some authors have described several subspecies of both "species" on the basis of their geographical variability, mainly from the Alps (Beuret, 1954) and mountainous areas of SE Europe (Fruhstorfer, 1917; Rebel \& Zerny, 1931; Szabó, 1956; Bálint, 1985, 1986).
As a consequence, there are contradictory statements in the literature about the taxonomic status of the Alcon Blues (M. alcon species group) in the Carpathian Basin. Populations occurring in humid habitats of western and central Hungary are generally treated as the nominotypic M. alcon alcon ([Denis \& Schiffermüller], 1775). In contrast, the populations living in xero-mesophilic habitats are either identified as M. alcon curiosa (Szabó, 1956), which was described from the Bükk Mts (Varga, 1961), or $M$. rebeli xerophila (Berger, 1946) or even $M$. xerophila (Bálint 1985, 1986). Populations of southern Transdanubia and the calcareous habitats of Transylvania are referred to either the balcanic $M$. alcon tolistus (Fruhstorfer, 1917) or the endemic subspecies of the Transylvanian mountains, M. alcon limitanea (Bálint, 1985). The initial food-plant data and the external morphological characters are, however, often contradictory. Some populations in NE Hungary (Zempléni Mts) using Gentiana pneumonanthe as a food plant show "rebeloid" characters, i.e. the females have a bluish "mirror" and strong discal spots on the forewing. In contrast, the Transylvanian populations exploiting Gentiana cruciata usually have unicolorous blackish-brown "alconoid" females, as do most of the Balcanic populations from the Slovenian Karst, Montenegro and northern Albania (see: $M$. alcon sevastos (Rebel \& Zerny, 1931)) and the mountaineous parts of western Bulgaria (Kolev, 2002).

\footnotetext{
* Corresponding author.
} 
Gentiana pneumonanthe is generally considered to be the initial food plant of M. alcon and Gentiana cruciata of $M$. rebeli. Alternative food plants, have also been reported recently (M. Dolek, pers. comm.; Sielezniew \& Stankiewicz, 2004; Z. Varga, pers. observ.). Both species are obligatorily myrmecophilous and belong to the so called cuckoo species. Their host ant specificity was considered to be the most significant evidence supporting their ranking as separate species (Elmes \& Thomas, 1987a, b; Thomas et al., 1989; Elmes et al., 1991a, b, 1994). In the Carpathian Basin, M. alcon mostly exploits Myrmica scabrinodis sometimes My. salina and My. vandeli. M. rebeli, however, uses several Myrmica species: mainly My. scabrinodis, My. sabuleti and My. schencki but sometimes also My. lonae and My. specioides (Tartally \& Csősz, 2004; Tartally \& Varga, 2006). These data essentially coincide with the "multi-species" host ant use of Austrian M. rebeli (Steiner et al., 2003; Schlick-Steiner et al., 2004).

In our previous study (Bereczki et al., 2005), the genetic structure of several Alcon Blue populations in Central Europe was reported. The results of that survey showed a high level of genetic differentiation among samples, which did not exhibit an evident species pattern. Moreover, the results of hierarchical $F$-statistics suggested that the geographic pattern was slightly more expressed in the between sample component of the genetic variation than the one based on the use of initial food plant (i.e. the traditional "species" pattern). We therefore concluded that the genetic structure of the Alcon Blue populations in Central Europe does not support the species status of $M$. alcon and M. rebeli, and refered to M. alcon as M. alcon "Pneumonanthe" type and $M$. rebeli as $M$. alcon "Cruciata" type. The high level of differentiation among the populations, without any clear taxonomic or geographic pattern, was assumed to be a consequence of strong genetic drift combined with local adaptation. Supposing that the geographic structure of genetic variation is the result of a balance between genetic drift and migration, the lack of this structure implies that differentiation is too strong to be counterbalanced by gene flow. For a particular species with given dispersal ability the efficiency of migration is mostly determined by the geographic distance between populations. Our previous results indicated that the distances between the regions in Central Europe were too great, i.e. the geographic scale of the survey was too large to detect the genetic consequences of migration in the geographic pattern of genetic variation. Accordingly, the aim of the present study was to analyse the pattern of genetic differentiation in Alcon Blue populations on a smaller geographic scale, e.g. within a region. Therefore, numerous populations in Northern Hungary, which belonged to both taxa and originated from several subregions were sampled. This enabled us to compare the species and geographic structure of genetic variation within this region of Central Europe.

\section{MATERIAL AND METHODS}

\section{Samples}

Both M. alcon "Pneumonanthe" and "Cruciata" type samples were collected from four subregions of Northern Hungary: Aggteleki Karst region and the Bükk, Mátra and Zempléni Mts (Fig. 1). In addition, two samples were collected from an isolated M. alcon "Pneumonanthe" type population near Fülesd on the Bereg Plain. Altogether 21 samples were collected from 11 populations between 2000 and 2003 (Table 1). The samples exhibited three different types of hierarchy: food plant/species pattern (food plant, population), geographic (subregion, population) and temporal (population, samples from a population taken in different years) patterns. Imagines were collected after the egg laying period in late June (M. alcon "Cruciata" type) or July (M. alcon "Pneumonanthe" type) and stored at $-80^{\circ} \mathrm{C}$ until required for electrophoresis. Sample sizes varied between 10 and 54, according to the size of the populations.

\section{Enzyme studies}

Allozyme polymorphism was studied at 16 different loci by vertical polyacrylamide gel electrophoresis: aconitase (Acon), alkaline phosphatase (Acph), aldehyde oxidase (Aox), esterase $(E s t)$, glutamate dehydrogenase $(G d h)$, glutamate oxalacetate transaminase (Got-1, Got-2), glucose-6-phosphate dehydrogenase $(G 6 p d h), \alpha$-glycerophosphate dehydrogenase $(\alpha G p d h)$, hexokinase $(H k)$, isocitrate dehydrogenase $(I d h)$, malate dehydrogenase $(M d h)$, malic enzyme $(M e)$, phosphoglucose isomerase $(P g i)$, phosphoglucomutase $(P g m)$, and superoxid dismutase $(S o d)$. Thoraxes homogenized in $300 \mu 1$ of extraction buffer were used to study Got-1, Got-2, $\alpha$ Gpdh, G6pgdh, Hk, $I d h, M d h, M e, P g i, P g m$, and Sod. Abdomens homogenized in $200 \mu \mathrm{l}$ of extraction buffer were used to analyse Acon, Acph, Aox, Est, and Gdh. The extraction buffer, the electrophoresis buffer systems and running conditions, together with the staining solutions used for each enzyme were all used according to Bereczki et al. (2005). Genotypes of the different individuals were scored according to their enzyme pattern.

\section{Statistical analyses}

Genotype and allele frequencies were calculated on the basis of banding patterns. Measures of genetic variation (average number of alleles, proportion of polymorphic loci, average observed heterozygosity, and number of multi-locus genotypes) were calculated for each sample. Genetic differentiation among the populations was first analysed by Wright's $F$-statistics (Wright, 1978; Weir, 1996). In this analysis, the total genetic variation of the samples $\left(F_{I T}\right)$ is partitioned into within $\left(F_{I S}\right)$ and between population components $\left(F_{S T}\right)$. The analyses were done using FSTAT version 1.2 (Goudet, 1995). An exact test for population differentiation (Raymond \& Rousset, 1995a) was also conducted to test for independence of the allelic composition of the populations. Genepop, version 1.0 (Raymond \& Rousset, 1995b) was used to perform this test. Allele frequencies were used to estimate Nei's genetic distances (Nei, 1972) and a UPGMA dendrogram (Sneath \& Sokal, 1973) was constructed on the basis of this data. The computation of genetic distances was performed using Biosys-1, Release 1.7 (Swofford $\&$ Selander, 1981). The distribution of the total genetic variation at various levels of the hierarchy was also studied using AMOVA (Excoffier et al., 1992; Weir, 1996). As the samples exhibited three different hierarchical patterns (food plant, geographic and temporal patterns) three series of hierarchical gene diversity analyses were performed. AMOVA was done using Arlequin ver 2.000 (Schneider et al., 2000). In the last part of the study, a principal component analysis (PCA) was done using the allele frequency data of the samples to show the size of 


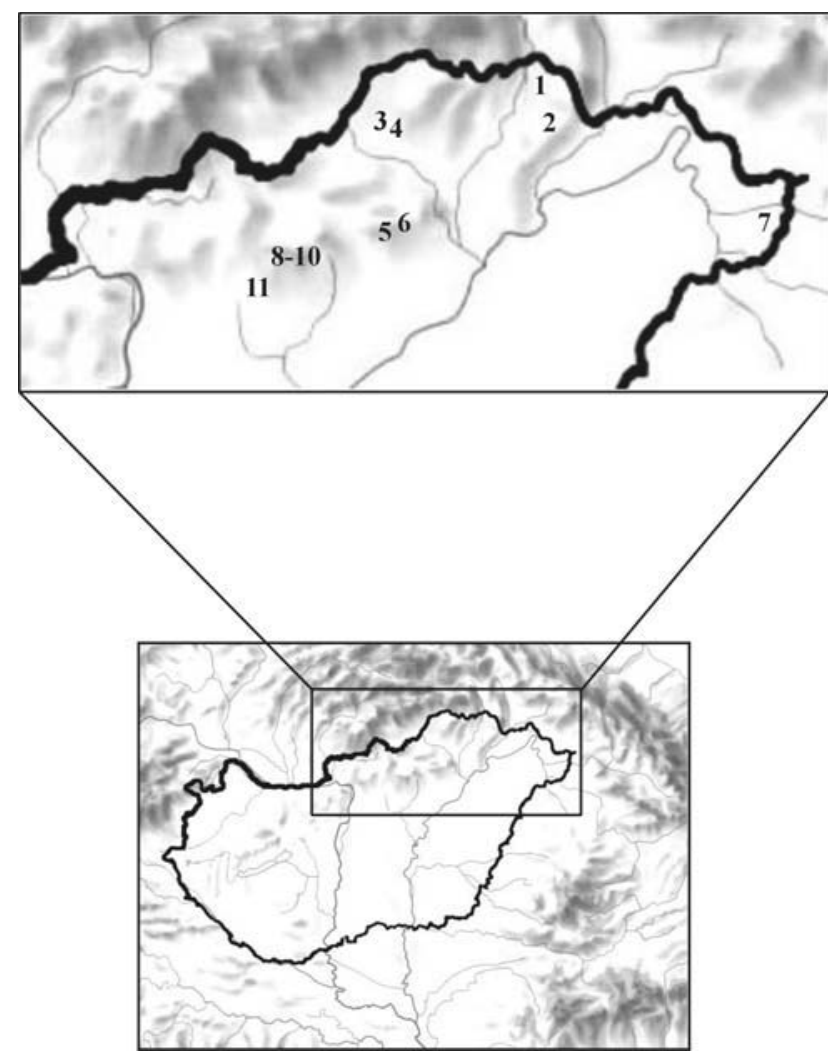

Fig. 1. Alcon Blue populations sampled in Northern Hungary. Zempléni Mts: 1 - Drahos meadow, 2 - Gyertyánkút; Aggtelek Karsts region: 3 - Kuriszlán, 4 - Tohonya; Bükk Mts: 5 Bükkszentkereszt, 6 - Bükk plateau; Bereg plain: 7 - Fülesd; Mátra Mts: 8 - Tugár, 9 - Jáger, 10 - Nyikom, 11 - Gyilkos.

overlap in the genetic variation of the populations in a reduced space of variables. $95 \%$ ellipses were drawn by the programme, which included $95 \%$ of the given samples. PCA analyses were performed using R Package Version 4.0 (Casgrain \& Legendre, 2001).

\section{RESULTS}

Three of the 16 loci (Gdh, G6pdh, Me) did not have alternative alleles in any of the samples investigated. The samples exhibited an average level of polymorphism. Over all, the percentage of polymorphic loci was $34 \%$ and the average frequency of heterozygotes was approximately $10 \%$ (Table 2). Heterozygote deficiency was observed in almost all populations, which proved to be significant in 5 cases out of the 11 (Table 3). The samples were grouped in two ways. First, they were split according to the initial food plant they use into "Pneumonanthe" and "Cruciata" type populations (Table 2). The parameters of genetic variation indicated a slightly higher level of polymorphism in the "Cruciata" type than in the "Pneumonanthe" type populations $\left(A-F_{1,19}=11.23\right.$, $0.001<P<0.01 ; P-F_{1,19}=0.95,0.05<P ; G-F_{1,19}=0.01$, $0.05<P$ ) with the exception of the average frequency of heterozygotes, which was relatively low and was coupled with a higher level of heterozygote deficiency in these populations. The next step was to sort the samples according to the subregions from which they originated
TABLE 1. Sample sites for Maculinea alcon-rebeli in the years from 2000 to 2003 (number of individuals/year). No.: Number of population on the map (Fig. 1.); Abbrev.: abbreviation of the populations in the dendrogram (Fig. 2.); Food plant (Fp.): p Gentiana pneumonanthe, c - G. cruciata; Subregion (Sr.): Z Zempléni Mts, M - Mátra Mts, A - Aggtelek Karsts region, B Bükk Mts, F - Fülesd.

\begin{tabular}{|c|c|c|c|c|c|c|c|c|}
\hline No. & Population & Abbrev. & Fp. & Sr. & 2000 & 2001 & 2002 & 2003 \\
\hline 1 & Drahos-meadow & Dra & $\mathrm{p}$ & Z & 11 & - & 15 & 23 \\
\hline 2 & Gyertyánkút & Gyk & $\mathrm{p}$ & $\mathrm{Z}$ & - & 11 & - & 17 \\
\hline 3 & Kuriszlán & Kuri & $\mathrm{c}$ & A & - & - & 50 & 22 \\
\hline 4 & Tohonya & Toh & $\mathrm{c}$ & A & - & 22 & 38 & 37 \\
\hline 5 & Bükk-platea & Bükk & $\mathrm{c}$ & B & - & - & 10 & 20 \\
\hline 6 & $\begin{array}{c}\text { Bükkszentker- } \\
\text { eszt }\end{array}$ & Bszk & c & B & - & 20 & 20 & - \\
\hline 7 & Fülesd & Fü & $\mathrm{p}$ & $\mathrm{F}$ & - & - & 31 & 22 \\
\hline 8 & Jáger-meadow & Jág & $\mathrm{p}$ & M & - & - & - & 20 \\
\hline 9 & Nyikom & Nyik & $\mathrm{p}$ & M & - & - & - & 10 \\
\hline 10 & Tugár-meadow & Tug & $\mathrm{p}$ & M & - & - & - & 20 \\
\hline 11 & Gyilkos-meadow & Gyr & $\mathrm{p}$ & $\mathrm{M}$ & - & - & 54 & 20 \\
\hline
\end{tabular}

(Table 2). The parameters did not show a clear-cut regional picture. The highest percentage of polymorphic loci was observed in the Bükk Mts $\left(F_{4,16}=2.42,0.05<\right.$ $P)$, however, these populations had an average number of multi locus genotypes and frequency of heterozygotes. The highest frequency of heterozygotes was found in populations from the Zempléni Mts $\left(F_{4,16}=0.82,0.05<\right.$ $P$ ), however they had an average number of alleles and percentage of polymorphic loci.

The results of $F$-statistics indicated a relatively high level of total variation (Table $4: F_{I T}$ ). A substantial portion of this variation was, however, observed among the samples. That is, the level of genetic differentiation was fairly high (Table $4: F_{S T}$, and the results of exact test). The samples were significantly differentiated at all but two ( $\alpha$ Gpdh and Pgi) of the 16 loci (Table 4). The within population variation was also sizeable. The average $F_{I S}$ value suggested significant heterozygote deficiency within the samples (Table 4). It was attributable to 4 of the 16 loci.

Nei's genetic distances were calculated and an UPGMA dendrogram constructed on the basis of the distance matrix. The dendrogram did not show an obvious species pattern (Fig. 2). The samples using different food plants were randomly scattered in the upper branch. Yet, the lower branch only contained the samples from the "Pneumonanthe" type populations from the Mátra Mts. The samples of one subregion tended to cluster in the same branch (e.g. Aggtelek Karst: Kuri03, Toh03, Kuri02, Toh01; Zempléni Mts: Dra03, Gyk03, Dra02; Bükk Mts: Bszk01, Bszk02, Bükk02) although there were exceptions (e.g. Gyk01 from the Zempléni Mts was clustered together with samples from the Bükk Mts). It is, however, remarkable that the samples originating from the same population but collected in different years (generations) were not clustered in the same branch (e.g. Dra00 vs. Dra02 or Dra03, Fül02 vs. Fül03, Gyk03 vs. Gyk01). 
TABLE 2. Parameters of enzyme polymorphism in the Northern Hungarian Alcon Blue populations averaged for samples from particular food plants and subregions. Numbers in brackets: samples in a given group. A: mean number of alleles per locus; P: percentage of polymorphic loci; $\mathrm{H}$ : mean frequency of heterozygotes; $F_{I S}$ : index of the within sample variation together with the proportion of samples with a significant value; G: average number of multi-locus genotypes estimated for 10 individuals.

\begin{tabular}{cccccccc}
\hline & & $\mathrm{A}$ & $\mathrm{P}$ & $\mathrm{H}$ & $F_{I S}$ & $\mathrm{G}$ \\
\hline Foodplant & G. pneumonanthe (12) & 1.43 & 32.8 & 0.105 & $\begin{array}{c}0.12 \\
(0.33)\end{array}$ & 8.26 \\
& G. cruciata (9) & 1.54 & 35.4 & 0.097 & $\begin{array}{c}0.213 \\
(0.78)\end{array}$ & 8.21 \\
\hline \multirow{4}{*}{ Zempléni (5) } & 1.44 & 33.8 & 0.114 & $\begin{array}{c}0.138 \\
(0.20)\end{array}$ & 9.10 \\
& Karst (5) & 1.58 & 32.5 & 0.096 & $\begin{array}{c}0.260 \\
(0.80)\end{array}$ & 7.73 \\
& Bükk (4) & 1.50 & 39.1 & 0.097 & $\begin{array}{c}0.156 \\
(0.75)\end{array}$ & 8.82 \\
& Fülesd (2) & 1.40 & 25.0 & 0.086 & $\begin{array}{c}0.069 \\
(0)\end{array}$ & 7.18 \\
& Mátra (5) & 1.42 & 35.0 & 0.104 & $\begin{array}{c}0.207 \\
(0.60)\end{array}$ & 7.85 \\
\hline & Total (21) & 1.49 & 34.1 & 0.102 & $\begin{array}{c}0.161 \\
(0.47)\end{array}$ & 8.24 \\
\hline
\end{tabular}

In the analysis of the structure of genetic differentiation, the "food plant" and the geographic patterns in the between sample variation, were compared. First we computed $F$-statistics on restricted data sets. In the first part of these analyses, the samples of the populations were grouped according to the food plant they used. The level of differentiation was relatively high among the "Pneumonanthe" $\left(F_{S T}=0.208,0.01>P>0.001\right)$ and low among the "Cruciata" type populations $\left(F_{S T}=0.024,0.01\right.$ $>P>0.001)$. The next step sorted the samples into the four subregions from which they originated. $F_{S T}$ values estimated for these four subregions separately were always substantially lower than the total (Total: 0.159 , $0.01>P>0.001$ vs. Karst: $0.011,0.01>P>0.001$; Bükk: 0.041, $0.01>P>0.001$; Mátra: 0.082, $0.01>P>$ 0.001; Zempléni 0.057, $0.01>P>0.001$ ).

Hierarchical $F$-statistics were computed using Arlequin. In this programme, the total genetic variation can also be analysed using the within sample component. However, it was not possible to include all levels of the hierarchy above the sample in a single run. The analyses were, therefore, conducted in three series. In the first two runs, the levels of hierarchy were: between groups of samples with different food plants or subregions, among samples within the groups, and within samples. In the third run, the levels of hierarchy were: among populations, between samples (years/generations) within a population, and within samples. The results suggested that most of the total genetic variation was attributable to the within sample component (Table 5: WS). Although the between sample component seemed to be low in these analyses (an average $10-11 \%$ of the total variation), the $F_{S T}$ value cal-
TABle 3. Parameters of enzyme polymorphism in the Alcon Blue populations investigated. \#: more than one sample was collected from the population. A: mean number of alleles per locus; P: percentage of loci polymorphic; H: mean frequency of heterozygotes; $\mathrm{F}_{\mathrm{IS}}$ : index of heterozygote deficiency. Levels of significance for $F_{I S}$ are given if all samples from the population had a significant value. ${ }^{*}$ : significant at 0.05 level; **: significant at 0.01 level.

\begin{tabular}{cccccl}
\hline Subregion & Population & $\mathrm{A}$ & $\mathrm{P}$ & $\mathrm{H}$ & \multicolumn{1}{c}{$F_{I S}$} \\
\hline \multirow{2}{*}{ Zemplén } & Drahos-meadow\# & 1.5 & 33.4 & 0.113 & 0.084 \\
& Gyertyánkút\# & 1.4 & 34.4 & 0.116 & 0.181 \\
\hline \multirow{2}{*}{ Karst } & Tohonya\# & 1.5 & 33.4 & 0.097 & $0.230^{* *}$ \\
& Kuriszlán\# & 1.7 & 31.3 & 0.097 & $0.261^{* *}$ \\
\hline \multirow{2}{*}{ Bükk } & Bükk-plateau\# & 1.5 & 37.6 & 0.088 & $0.238^{*}$ \\
& Bükkszentkereszt\# & 1.5 & 40.7 & 0.107 & 0.122 \\
\hline \multirow{2}{*}{ Fülesd } & Fülesd\# & 1.4 & 25.0 & 0.087 & 0.069 \\
\hline \multirow{3}{*}{ Mátra } & Tugár & 1.4 & 37.5 & 0.135 & 0.029 \\
& Nyikom & 1.5 & 43.8 & 0.123 & $0.249^{*}$ \\
& Jáger-meadow & 1.4 & 37.5 & 0.115 & 0.128 \\
& Gyilkos-meadow\# & 1.4 & 28.2 & 0.073 & $0.304^{* *}$ \\
\hline
\end{tabular}

culated by the programme $(0.167 ; P<0.001)$ was in agreement with that estimated using $F$-statistics. The distribution of the between sample variation indicated a sizeable level of differentiation among the samples/ generations collected from the same population (Table 5: WP). The index of differentiation calculated for this level of hierarchy was highly significant $\left(F_{S P}=0.091 ; P<\right.$ 0.001). The differences between the populations using different food plants accounted for a lower percentage of the total between sample variation (i.e. total level of differentiation) than of that among the subregions (Table 5: BFp vs. BSr). The indices of differentiation suggested a similar tendency. The index representing the level of differentiation among the subregions was relatively high $\left(F_{S r T}=0.107 ; P<0.001\right)$. Although the index of differentiation among populations using different food plants was also significant $\left(F_{F p T}=0.063 ; 0.05>P>0.01\right)$ it was much lower than $F_{S r T}$.

The results of the PCA analyses fully confirmed the lack of a species pattern in the genetic differentiation among the samples. The samples exhibited one large cloud of points in the reduced space of variables (Fig. 3A and $3 \mathrm{~B}$ ). The two axes explained more than $70 \%$ of the total variation (axis 1: $52.72 \%$; axis 2: 19.39\%). When the $95 \%$ ellipses were drawn according to the food plants they nearly completely overlapped. It is interesting though that the "Pneumonanthe" type exhibited a higher level of differentiation than the "Cruciata" type samples (Fig. 3A). At the same time the pattern became much clearer when the $95 \%$ ellipses were drawn on the basis of the geographic origin of the samples (Fig. 3B). In accordance with the dendrogram the samples from the Mátra Mts were clearly differentiated from the others. This was most expressed along the first axis, which was predominantly determined by the Est locus. The two samples from the Fülesd population were also differentiated from the 


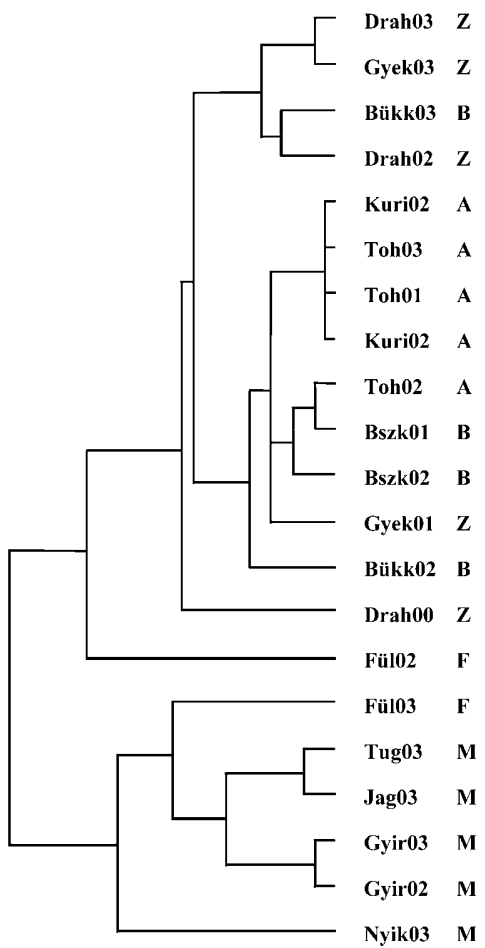

Fig. 2. UPGMA dendrogram constructed using of Nei's genetic distances among the 21 Alcon Blue samples. The numbers after the abbrevations of the populations indicate the year of collection. 00: 2000; 01: 2001; 02: 2002; 03: 2003. Capital letters represent the subregions. A: Aggtelek karsts region; B: Bükk Mts; F: Fülesd (isolated population on the Bereg Plain); M: Mátra Mts; Z: Zempléni Mts.

others along the second axis, which was mostly affected by the allele frequency distribution at the Acon locus. The other three subregions exhibited a relatively lower level of differentiation as their $95 \%$ ellipses partially overlapped.

\section{DISCUSSION}

The results of the present study suggest a high level of differentiation among the samples investigated. Moreover, a sizeable amount of the total between sample variation could be attributed to differences among the samples collected in consecutive years from a population. That is, a considerable fluctuation in allele frequencies occurred from generation to generation. These findings are consistent with our former results (Bereczki et al., 2005) and imply a strong effect of genetic drift, which is expected because of the life cycle of the Alcon Blues.

Both the "Pneumonanthe" and "Cruciata" type of Maculinea alcon are dependent on the presence of two sequential resources, the food plant (G. pneumonanthe or G. cruciata) and a species of red ant (mostly Myrmica scabrinodis for M. alcon "Pneumonanthe" type and My. sabuleti, My. scabrinodis or My. schencki for the "Cruciata" type). The imagines oviposit on the specific food plants regardless of whether they grow near nests of the
TABLE 4. Results of F-statistics and exact test of population differentiation computed for all 21 samples regardless of their food plant or geographic origin. $F_{I T}$ : total genetic variation; $F_{S T}$ : between sample component of variation; $F_{I S}$ : within sample component of variation. ns: not significant; *: significant at 0.05 level; **: significant at $0.01 \mathrm{level} ; * * *$ : significant at 0.001 level.

\begin{tabular}{ccccc}
\hline Locus & $\mathrm{F}_{\mathrm{IT}}$ & $\mathrm{F}_{\mathrm{ST}}$ & $\mathrm{F}_{\mathrm{IS}}$ & Exact test \\
\hline Acon & $0.438^{* *}$ & $0.137 * *$ & $0.350^{* *}$ & $* * *$ \\
Acph & $0.212^{* *}$ & $0.049^{* *}$ & $0.172^{* *}$ & $* * *$ \\
Aox & $0.197 * *$ & $0.090^{* *}$ & $0.117 * *$ & $* * *$ \\
Est & $0.723^{* *}$ & $0.378^{* *}$ & $0.554^{* *}$ & $* * *$ \\
G6pdh & - & - & - & - \\
Gdh & - & - & - & - \\
Got1 & -0.013 & $0.074^{* *}$ & -0.094 & $* * *$ \\
Got2 & -0.017 & $0.023^{* *}$ & -0.041 & $* *$ \\
Gpdh & -0.001 & 0.006 & -0.007 & $*$ \\
Hk & $-0.006 *$ & $0.057 * *$ & -0.067 & $* * *$ \\
Idh & $0.130 * *$ & $0.079 * *$ & 0.055 & $* * *$ \\
Mdh & -0.051 & $0.132 * *$ & -0.211 & $* * *$ \\
Me & - & - & - & - \\
Pgi & -0.009 & 0.004 & -0.013 & $*$ \\
Pgm & 0.042 & $0.054 * *$ & -0.012 & $* * *$ \\
Sod & -0.004 & $0.095^{* *}$ & -0.109 & $* * *$ \\
\hline All loci & $0.324 * *$ & $0.159 * *$ & $0.197 * *$ & $* * *$ \\
\hline
\end{tabular}

host ant (Elmes \& Thomas, 1987a, b). The young larvae first feed in the fruit capsules, developing through three larval instars (Thomas et al., 1989). When they reach the fourth instar they drop to the ground and wait to be discovered by foraging workers of particular Myrmica species, who adopt and take them to their nest. Maculinea alcon is a cuckoo species, i.e. it is fed by the nursing ant workers (Elmes et al., 1991a, b). This stage of the life cycle is, therefore, a great hazard for Alcon Blues. Many of the larvae that drop off food plants are not found by ants or are neglected. In addition, strong competition may occur among the larvae when an ant's nest is crowded and nurse ants are in short of supply (Elmes et al., 1991a). Under these conditions survival may decrease dramatically due to ants selecting to tend only a few caterpillars. As a consequence of these chance events most of the

TABLE 5. Distribution of variation at different levels of the hierarchy: Food plant - between food plant (BFp), within food plant between the samples (WFp + WP), within samples (WS). Subregion - between subregions (BSr), within subregion between the samples (WSr + WP), within samples (WS). Population - between populations (BFp/BSr + WFp/WSr); between the samples within populations (WP); within samples (WS).

\begin{tabular}{|c|c|c|c|}
\hline & Food plant & Subregion & Population \\
\hline $\mathrm{BFp} / \mathrm{BSr}$ & $\begin{array}{c}1.23 \\
(11.99)\end{array}$ & $\begin{array}{c}7.29 \\
(66.39)\end{array}$ & \multirow{2}{*}{$\begin{array}{c}8.03 \\
(78.65)\end{array}$} \\
\hline WFp/WSr & \multirow{2}{*}{$\begin{array}{c}9.03 \\
(88.01)\end{array}$} & \multirow{2}{*}{$\begin{array}{c}3.69 \\
(33.61)\end{array}$} & \\
\hline WP & & & $\begin{array}{c}2.18 \\
(21.35)\end{array}$ \\
\hline WS & 89.74 & 89.02 & 89.79 \\
\hline
\end{tabular}


A

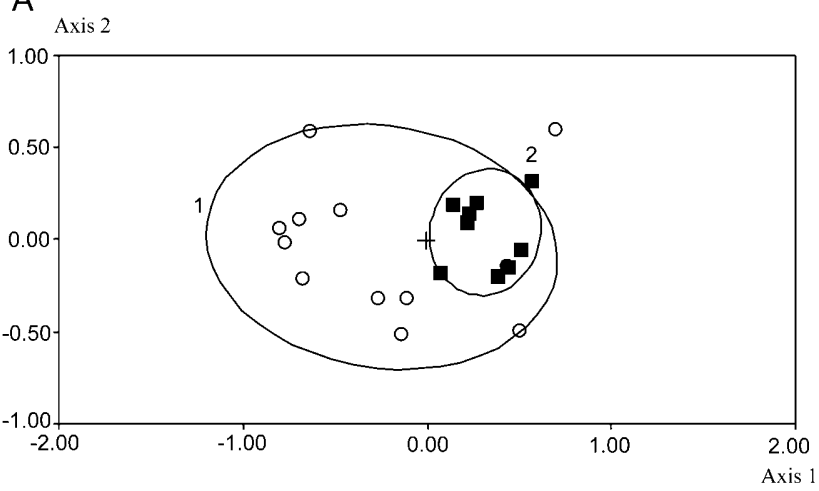

B

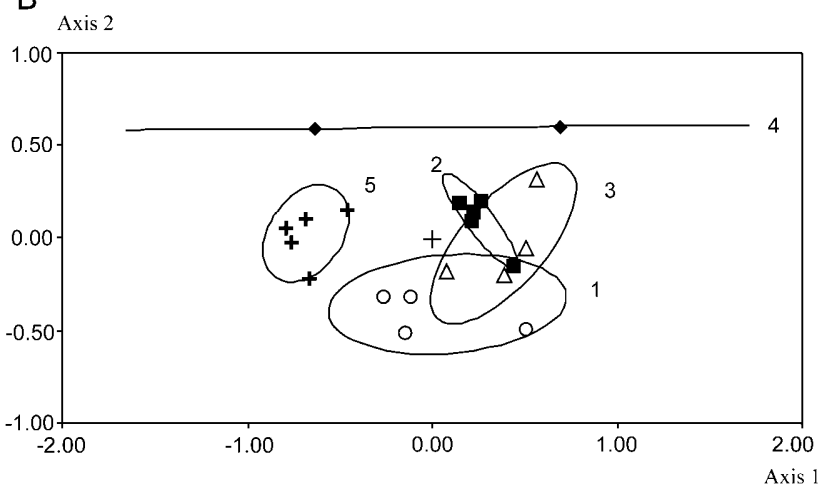

Fig. 3. Results of the PCA analyses. Each point represents a sample in the reduced space of variables. A $-95 \%$ ellipses are drawn according to their food plant. 1: G. pneumonanthe; 2: G. cruciata. B - 95\% ellipses are drawn according to the subregion. 1: Zemplén Mts; 2: Aggtelek Karts region; 3: Bükk Mts; 4: Fülesd; 5: Mátra Mts.

larvae die and only a small percentage of them become adults. In other words, the Alcon Blues experience a bottleneck in every generation. Owing to repeated bottlenecks Maculinea populations are exposed to the effect of genetic drift.

As a consequence of drift Alcon Blue populations exhibit a relatively low level of genetic variation. They are much less polymorphic than other lycaenid butterflies (e.g. Plebejus argus: Thomas et al., 1998; Polyommatus coridon, P. bellargus, P. icarus: Schmitt, 1999; Schmitt et al., 2002, 2003; Schmitt \& Hewitt, 2004; Schmitt \& Seitz, 2001, 2002a, b; Aricia artaxerxes: Aagard et al., 2002; K. Pecsenye unpubl. data). Our results are comparable with those of Gadeberg \& Boomsma (1997) for a Danish populations of $M$. alcon. They also found a relatively low level of variation at the loci investigated. Nevertheless, our expectation was that drift would affect the level of polymorphism in small and large populations differently. It was, therefore, interesting to compare the parameters of polymorphism among populations of different sizes. The results did not show a consistent pattern (Table 2 and Table 3). Some of the large populations had an unexpectedly low frequency of heterozygotes e.g. the two populations from the Karst region, which have increased considerably over the last few years as a consequence of active management (Árnyas et al., 2006). At the same time, some relatively small populations had a high percentage of heterozygotes (e.g. the two populations from the Zempléni Mts). The low level of heterozygosity was often coupled with a significant $F_{I S}$ value (see Table 3). This was, however, detected in both small and large populations (small e.g. Bükk plateau, large e.g. Tohonya, Kuriszlán in the Aggtelek Karst region). Moreover, heterozygote deficiency seemed to be consistent over generations. All this evidence suggests that in Alcon Blues, the background of heterozygote deficiency might be some kind of subpopulation structure. The pattern of this fine structure within the populations, however, seemed to be unique in every case and therefore requires further detailed studies. This assumption is also supported by other studies (Gadeberg \& Boomsma, 1997). They found that Large Blue populations exhibit a high level of genetic differentiation coupled with significant heterozygote deficiency. Thus they conclude that the populations they sampled consisted of several partially isolated gene pools. At the same time, the high $F_{S T}$ values indicate that the fine genetic structure of the populations were different in different regions.

The other consequence of drift is a strong genetic differentiation among the populations. The results of the present analysis and also our previous one (Bereczki et al., 2005) fully support the strong differentiation among the Alcon Blue populations. At the same time there are clear differences between the two studies. In our previous report, the populations sampled could be sorted into four large regions in Central Europe and yet there was no evidence of a geographic pattern of differentiation. Hence we concluded that the geographic distances among these regions were too large relative to the dispersal ability of the butterflies and, therefore, gene flow did not counterbalance genetic differentiation. In the present study, our working hypothesis is that migration must be more intensive over a smaller geographic scale (e.g. among populations within subregions). Thus, we expected a clear geographic pattern of genetic variation within the Northern Hungarian region. The results of PCA, AMOVA and hierarchical $F$-statistics confirmed our expectations. The differentiation among the subregions in Northern Hungary was as high as that among the populations within the subregions. Gadeberg \& Boomsma (1997) also found regional differences in allele frequency distributions among Danish populations of M. alcon. Since the geographic scales of the two studies were comparable, the similar results indicate that geographic distances between the populations within the regions are similar to the distances Alcon Blues migrate.

Nonetheless, the dendrogram (Fig. 2) showed that the separation among the samples originating from the Bükk Mts, Aggtelek Karst region and Zempléni Mts were not complete. The first branch mostly contained samples collected in the Zempléni Mts, the second branch those collected in the Karst region and the third those from the Bükk Mts Yet, one sample collected on the Bükk plateau was clustered together with those from the Zempléni Mts and one Gyertyánkút sample (Zempléni Mts) with the samples from the Bükk Mts. The results of the PCA also 
indicated that the samples from the Bükk and Zempléni Mts were not clearly different from each other. One possible explanation of the lack of clear separation between these subregions might be that their similarity in genetic structure is simply a result of chance events.

As in our previous study (Bereczki et al., 2005), the present results did not show a species pattern of differentiation among the samples analysed. Although some percentage of the total between sample variation was attributable to differences between the two sets of populations using different food plants, this variation could be explained by the clear differentiation between the samples from the Mátra Mts and all others, since all these samples originated from "Pneumonanthe" type populations. It thus appears that the genetic differentiation of the Alcon Blue populations is not consistent with their ecological differentiation.

ACKNOWLEDGEMENTS. The study was supported by the MacMan EVK2-CT-2001-00126 project. The authors are grateful to J. Settele, E. Kuehn, and S. Gwyllim for the management of the project. The technical assistance of V. Mester with the electrophoretic work is greatly appreciated as is the support of the Nature Conservation Authorities of Hungary.

\section{REFERENCES}

Aagard K., Hindar K., Pullin A.S., James C.H., Hammarstedt O., Balstad T. \& Hanssen O. 2002: Phylogenetic relationships in brown argus butterflies (Lepidoptera, Lycaenidae: Aricia) from North-Western Europe. Biol. Linn. Soc. 75: $27-37$.

Als T.D., Vila R., Kandul N.P., Nash D.R., Yen S-H., Hsu Y-F., Mignault A.A., Boomsma J.J. \& Pierce N.E. 2004: The evolution of alternative parasitic life histories in Large Blue butterflies. Nature 432: 386-390.

Árnyas E., Bereczki J., Tóth A., Pecsenye K. \& Varga Z. 2006: Egg-laying preferences of the xerophilus ecotype of Maculinea alcon (Lepidoptera: Lycaenidae) in the Aggtelek National Park. Eur. J. Entomol. 103: 587-595.

BÁLINT Z. 1985: Maculinea alcon limitanea nov. ssp. (Lepidoptera: Lycaenidae) from Transylvania, Rumania. Galathea (Nürnberg) 1/3: 62-74.

BÁLINT Z. 1986: Further studies on Maculinea alcon Den. and Schiff., 1775 (Lepidoptera: Lycaenidae). Galathea (Nürnberg) 2/4: 92-108.

Bereczki J., Pecsenye K., Peregovits L. \& Varga Z. 2005: Pattern of genetic differentiation in the Maculinea alcon species group (Lepidoptera, Lycaenidae) in Central Europe. Syst. Zool. Evol. Res. 43: 157-165.

Berger L. 1946: Maculinea rebeli Hirschke, bona species. Lambillionea 46: 95-110.

Bernardi G. 1947: Notes à propos d'un article de L. Berger Maculinea rebeli Hirschke bonne espèce. Bull. Soc. Entomol. Mulhouse 7-8: 61-67.

Beuret H. 1949: Contribution à l'étude du groupe Maculinea alcon Schiff. - rebeli Hirschke. Bull. Soc. Entomol. Mulhouse 1-7: 8 .

Beuret H. 1954: Die Lycaeniden der Schweiz. Teil II. Entomologische Gesellschaft, Basel, pp. 204-222.

CAsgrain P. \& Legendre P. 2001: The R package for multivariate and spatial analysis, version $4.0 \mathrm{~d} 5$ User's manual. Web site <http://www.fas.unmontreal.ca/BIOL/legendre/>
Ebert G. \& Rennwald E. 1991: Die Schmetterlinge BadenWürttenbergs. Bd. 2. Tagfalter II. Ulmer, Stuttgart, pp. 284-296.

Elmes G.W. \& Thomas J.A. 1987a: Die Gattung Maculinea. In: Schweizerische Bund für Naturschutz. Tagfalter, Basel, pp. 354-368.

Elmes G.W. \& Thomas J.A. 1987b: Die Biologie und Ökologie der Ameisen der Gattung Myrmica. Tagfalter und ihre Lebensräume. Schweizerische Bund für Naturschutz, Arten, Gefährdung, Schutz, Basel, pp. 404-409.

Elmes G.W., Thomas J.A. \& Wardlaw J.C. 1991a: Larvae of Maculinea rebeli, a large blue butterfly and their Myrmica host ants, patterns of growth and survival. J. Zool. 224: 79-92.

Elmes G.W., Thomas J.A. \& Wardlaw J.C. 1991b: Larvae of Maculinea rebeli, a large blue butterfly and their Myrmica host ants. Wild adoption and behaviour in ants nests. J. Zool. 223: 447-460.

Elmes G.W., Thomas J.A., Hammarstedt O., Munguira M.L., Martin J. \& VAN DER MADE J. 1994: Differences in host ant specificity between Spanish, Dutch and Swedish populations of the endangered butterfly, Maculinea alcon (Den. \& Schiff., 1775) (Lepidoptera). Memor. Zool. 48: 55-98.

Excoffier L., Smouse P. \& Quattro J. 1992: Analysis of molecular variance inferred from metric distances among DNA haplotypes: Application to human mitochondrial DNA restriction data. Genetics 131: 479-491.

Fruhstorfer H. 1917: Neue palearktische Lycaeniden. Iris 31: 24-25.

GADEBERG R.M.E. \& Boomsma J.J. 1997: Genetic population structure of the large blue butterfly Maculinea alcon in Denmark. J. Insect Conserv. 1: 99-111.

GOUDET J. 1995: Fstat version 1.2: a computer program to calculate F-statistics. J. Hered. 86: 485.

KAABER S. 1964: Studies on Maculinea alcon (Schiff.) - rebeli (Hir.) (Lep. Lycaenidae) with reference to the taxonomy, distribution and philogeny of the group. Entomol. Meddr. 33: 277-319.

Kolev Z. 2002: The species of Maculinea van Ecke, 1915 in Bulgaria: distribution, state of knowledge and conservation status (Lycaenidae) Nota Lepid. 25: 177-190.

Munguira M.L. \& Martin J. 1999: Action Plan for the Maculinea Butterflies in Europe. Council of Europe, Strasbourg, pp. 1-96.

NEI M. 1972: Genetic distance between populations. Am. Nat. 106: 283-292.

Pech P., Fric Z., Konvička M. \& ZrzavÝ J. 2004: Phylogeny of Maculinea blues (Lepidoptera: Lycaenidae) based on morphological and ecological characters: evolution of parasitic myrmecophily. Cladistics 20: 362-375.

RAYMOND M. \& Rousset F. 1995a: An exact test for population differentation. Evolution 49: 1280-1283.

RAYMOND M. \& Rousset F. 1995b: GENEPOP ver.1.2, a population genetics software for exact tests and ecumenicism. $J$. Hered. 86: 246-249.

Rebel H. \& Zerny H. 1931: Die Lepidopterenfauna Albaniens (mit Berücksichtigung der Nachbargebiete). Denkschr. Mathem.-Naturwiss. Klasse 103: 38-160.

Schlick-Steiner B.C., Steiner F.M., Höttinger H., Nikiforov A., Mistrik R., Schafellner Ch., Baier P. \& Christian E. 2004: Aggregate-odour multi-host mimicry: A butterfly's chemical key to various ant forts. Naturwissenschaften 91: 209-214.

Sснмітт T. 1999: Phylogeographie europaischer Tagfalter basierend auf populations-genetischen Analysen. PhD Dissertation, Johannes Gutenberg Universitat, Mainz, 131 pp. 
Schmitt T., Giessl A. \& Seitz A. 2002: Postglacial colonisation of western Central Europe by Polyommatus coridon (Poda, 1761) (Lepidoptera, Lycaenidae): evidence from population genetics. Heredity 88: 26-34.

Schmitt T., Giessl A. \& Seitz A. 2003: Did Polyommatus icarus (Lepidoptera, Lycaenidae) have distinct glacial refugia in southern Europe? Evidence from population genetics. Biol. J. Linn. Soc. 80: 524-538.

Sснмiтt T. \& Hewitt G.M. 2004: The genetic pattern of population threat and loss: a case study of butterflies. Mol. Ecol. 13 21-31.

Schmitt T. \& Seitz A. 2001: Allozyme variation in Polyommatus coridon (Poda, 1761) (Lepidoptera, Lycaenidae): identification of ice-age refugia and reconstruction of postglacial expansion. J. Biogeogr. 28: 1129-1136.

Schmitt T. \& Seitz A. 2002a: Postglacial area expansion of Polyommatus coridon (Lepidoptera, Lycaenidae) from its Ponto-Mediterranean glacial refugium. Heredity 89: 20-26.

Schmitт T. \& Seitz A. 2002b: Influence of habitat fragmentation on the genetic structure of Polyommatus coridon (Lepidoptera, Lycaenidae): implications for conservation. Biol. Conserv. 107: 291-297.

SchNeIDER S., Roessli D. \& Excoffier L. 2000: Arlequin ver. 2.000: A software for population genetic data analysis. Genetics and Biometry Laboratory, University of Geneva, Switzerland

Sielezniew M. \& Stankiewicz A.M. 2004: Gentiana cruciata as an additional food plant of Maculinea alcon on a site in eastern Poland (Lycaenidae). Nota Lepid. 27: 91-93.

SNeath P.H. \& Sokal R.R. 1973: Numerical Taxonomy. W.H. Freeman, San Francisco, 573 pp.

Steiner F.M., Sielezniew M., Schlick-Steiner B.C., Höttinger H., Stankiewicz A. \& GóRnicki A. 2003: Host specificity revisited: New data on Myrmica host ants of the lycaenid butterfly Maculinea rebeli. J. Insect Conserv. 7: 1-6.
Swofford D.L. \& Selander R.B. 1981: Biosys-1: A FORTRAN program for the comprehensive analysis of electrophoretic data in population genetics and systematics. J. Hered. 72: 281-283.

SzABó R. 1956: Magyarország Lycaenidái - Die Lycaeniden Ungarns. Folia Entomol. Hung. 9: 254-362.

TARTAlly A. \& VARGa Z. 2006: Host-ant specificity of Maculinea species in Hungary, connections with parasitoids and host plants. In Settele J., Kühn E. \& Thomas J.A. (eds): Studies on the Ecology and Conservation of Butterflies in Europe. Vol. 2: Species Ecology along a European Gradient: Maculinea Butterflies as a Model. Pensoft, Sofia-Moscow, pp. 94-98.

Tartally A. \& Csösz S. 2004: Data on the host ants of Maculinea butterflies (Lepidoptera: Lycaenidae) in the Carpathian Basin. Természetvédelmi Közlemények 11: 309-317.

Thomas J.A., Elmes G.W., Wardlaw J.C. \& Woyciechowski M. 1989: Host specificity among Maculinea butterflies in Myrmica host nests. Oecologia 79: 452-457.

Thomas C.D., HiLl J.K. \& Lewis O.T. 1998: Evolutionary consequences of habitat fragmentation in a localised butterfly. $J$. Anim. Ecol. 67: 485-497.

URBAHN E. 1964: Neuere Auffassungen in der Maculinea alconrebeli-Frage (Lepidoptera, Lycaenidae). Entomol. Abh. (Dresden) 32: 69-77.

VARGA Z. 1961: [Zoogeographical survey of the Macrolepidoptera-fauna of the N-Hungarian Karst area.] Folia Entomol. Hung. 14: 345-386 [in Hungarian, with German abstr.].

WeIR B.S. 1996: Genetic Data Analysis II: Methods for Discrete Population Genetic Data. Sinauer Assoc., Sunderland, 445 pp.

Wright S. 1978: Evolution and the Genetics of Populations. Vol. 4. Variability Within and Among Natural Populations. University of Chicago Press, Chicago, 590 pp.

Received November 6, 2005; revised and accepted March 20, 2006 